The role of Metchnikoff in science was the subject of a special paper read by Vassili Parin, general secretary of the Academy of Medical Science. "Metchnikoff," he said, "who obtained such important results in his theoretical work, did not despise practice and gave much time to find a scientific basis for fighting infections and epidemics such as cholera, typhoid and tuberculosis. His philosophy was full of optimism and faith in humanity and in the final triumph of science."

Metchnikoff died in 1916, but his numerous pupils in the Soviet Union pursued on a large scale his microbiological research for the welfare of the people.

The Opera House meeting was the first of a series of conferences extending over several days, at which reports were presented on various problems of bacteriology, and papers read on Metchnikoff's philo: sophical conceptions and his work in the fields of Darwinism, zoology, embryology, immunity, parasitology, microbiology and epidemiology.

To mark the centenary, the Soviet Government has decided to erect a monument to Metchnikoff in Moscow and to put memorial tablets in the University of Kharkov, where he was a student, and in the University of Leningrad, where he lectured. The University of Odessa, where he occupied a professorial chair, will bear his name. Metchnikoff gold medals and prizes are to be awarded by the Moscow Academy of Sciences, and Metchnikoff scholarships for students and research workers are to be founded by the Academy of Medicine and by the Medical Institutes of Kharkov, Moscow, Leningrad and Odessa. A biography of Metchnikoff is to be published, together with a uniform edition of his complete works; and $a$ film on his life and work will be issued in 1946.

LyDIA BACH.

\section{SCIENTIFIC AND INDUSTRIAL RESEARCH IN CANADA}

A PRELIMINARY review of the work of the A National Research Council of the Dominion of Canada in 1944, issued by the Research Plans and Publications Section, in addition to indicating the way in which the Council organizes and co-ordinates the national co-operative research programmes, outlines a few of the major items in the work under the Council's direction.

In aerodynamies, some of the new work involves such problems as balancing of controls on aircraft, work on aircraft skis, the design of tailless aircraft and investigation of factors which arise in their operation. In hydrodynamics there are two main fields: model-testing and basin-tests on aircraft floats and seaplanes, and hydraulic studies on harbour and river problems, in which such factors as silting, tidal effects, turbulence, location of piers, etc., are involved. Much test work is done on aircraft engines, and unsuspected savings in aviation fuel consumption have been achieved by developing a new type of cracked fuel which can be used in place of straightrun gasoline in certain operations. Photography has been utilized to study droplets in clouds surrounding aircraft in flight, and physical chemistry has shown a way of dispelling the raindrops which fall on the pilot's turret and tend to obscure his vision.

In the field of applied biology, war requirements have placed great emphasis on the need for work on foods and their preservation and mothods of transport. The development of canning methods for chicken, pork and ham has been undertaken as part of the war effort, and the industrial utilization of agricultural products is an important branch of work. The shortage of rubber led to the study of fermentation methods for the production from wheat of butylene glycol, recently shown to be useful as an anti-freeze, as well as a basis for the production of many useful chemicals. Methods are being developed for modifying wheat starch as a substitute for other starches and for the production of syrups and sugars. A pilot plant using a mechanical method for extracting resin rubber from native plant materials such as milkweed is in full operation.

The activities of the Division of Chemistry have involved much research on adapting substitute materials to war requirements and in developing new mothods for strategic chemicals. Substantial advances have been made in the technique of rot-proofing, flame-proofing, and water-repellency treatment of fabrics. The synthesis of new toxic compounds has been carried on as part of the programme of the Directorate of Chemical Warfare and Smoke. Alkaloids from Canadian plants continue to receive attention, and the Paint Laboratory has been occupied with the development of new protective coatings. A new method of glueing based on electrical resistance has been developed and is in commercial use. Research on the prevention of corrosion by the use of inhibitors is continuing, as well as on the protection of aluminium alloys against sea water. Work has also been carried out on the photosensitized polymerization and hydrogenation of butadiene.

In the Division of Physics and Electrical Engineering much work has been done during the War on the detection of sound under water at ultra-sonic frequencies. The General Physics Laboratory facilities have been used in such problems as measurement of muzzle vibrations of rifle bullets, ballistics cameras, vibrational measurements, construction and testing of fire-control apparatus, counter chronographs, automatic plotter for air-ground training and other work for the Armed Services. Much work of the Heat Laboratory has been suspended, but infra-red studies and work on land-mine detectors have been carried out with success. The Optics Laboratory has made a substantial contribution to the war effort, and can claim a fair share of credit for the establishment of an optical glass industry in Canada, besides contributing largely to aerial photography. The radio staff has grown to several hundreds, with special laboratories constructed to meet demands for radar studies, and post-war applications may include air-navigation methods, improved blind-landing technique, compact recognition equipment for all types of ships and aircraft and new types of shore beacons to supplement lighthouses, anti-collision alarm signals, otc. Industrial radiology has opened up a wide field of inspection which has been applied in the non-destructive detection of flaws in metal. The X-ray diffraction study of materials is becoming increasingly useful as new techniques are discovered, and electron microscopy is also providing the physicist and chemist with fundamental data not previously attainable.

The National Research Council has devoted much time and thought to preparation for the post-war period, and, under pressure of war, Canada is already spending five times as much on research as in the pre-war years. 